\title{
Effect of Capital Structure on the Performance of Deposit Money Banks
}

\author{
Abdulrashid Ibrahim Sadiq ${ }^{1}$ \\ Pofi Wendy Kachollom ${ }^{2}$ \\ Saminu Inuwa Dasuki ${ }^{3}$ \\ Mohammad Yusuf ${ }^{4}$
}

\begin{abstract}
${ }^{1+2+3+4}$ Department of Accounting and Finance, Abubakar Tafawa Balewa University Bauchi, Nigeria
Correspondence: Abdulrashid Ibrahim Sadiq, Department of Accounting and Finance, Abubakar Tafawa Balewa University Bauchi, Nigeria.Tel: +2348128369711.E-mail: mohammed.abdullah@mediu.edu.my
\end{abstract}

Received: August 27, 2017

Accepted: August 28, 2017

Online Published: August 31, 2017

\section{Abstract}

The objective of this study is to examine the effect of capital structure onthe financial performance of Deposit Money Banks in Nigeria. Secondary data was obtained from the financial statements of Deposit Money Banks listed in the Nigerian Stock Exchange.Four banks were selected as samples and data from their financial statements for a period of 10 years (2006-2015). The study has employed the use of Pearson correlation coefficient and GLS regression model to analyze the effect of capital structure on the performance of some selected. The performance variables used in the study were, Return on Asset (ROA), Return on Equity (ROE) and Return on Capital Employed (ROCE). Findings from the study showed that capital structure has an effect on the financial performance of listed deposit money banks in Nigeria.Based on the results, the study recommends thatdeposit money banks in Nigeria should employ an appropriate mix of debt and equity capital and strike a balance between their choice of capital structure and its effect on their performance, as this will affect the shareholders risk returns and the cost of capital. Furthermore, the banks should increase their assets as this will help them to be more positioned for better performance and the government should improve liquidity in the Nigerian Financial Market to enable deposit money banks raise long term debt and reduce over dependency on short term debt.

Keywords: Capital Structure, Financial Performance, Debt, Equity.

\section{Introduction}

Capital is essentially the lifeblood of any business activity. In fact, it serves as catalyst in establishing and promoting business firms. It plays a very resuscitative role especially in a country like Nigeria. Lessons from history reveal that most Deposit Money Banks collapsed as a result of inadequacy, mismanagement or lack of capital. So, Financing is one of the crucial areas in a firm. A financing manager is concerned with the determination of the best financing mix and combination of debts and equity for his firm.

Capital structure in financial term means the way firm finances their assets though the mixture of equity, debt, or hybrid securities (Saad, 2010). Therefore, capital structure here reveals the fusion of debts (long term and 


\section{Sadiq et al.}

short term), common equity, and preferred equity (Akintoye, 2008). Capital structure is fundamentally on how a firm finances its overall operations and growth by using diverse sources of fund (Tsuji, 2011). There are two components of capital structure which include internal fund (Retained Earnings) and External fund (debt and equity), Myles (1984). However, there are various alternatives of debt-equity ratio, these includes; 100\% equity: 0\% debt, 0\% equity: 100\% debt and X\% equity: Y\% debt (Dare \& Sola 2010). From these three alternatives, option one is that of the unlevered firm, that is, the firm that shuns the advantage of leverage (if any). Option two is that of a firm that has no equity capital. This option may not actually be realistic or possible in the real life economic situation, because no provider of funds will invest his money in a firm without capital. This partially explains the term "trading on equity", that is, it is the equity element that is present in the firm's capital structure that encourages the debt providers to give their scarce resources to the business. Option three is the most realistic one in that, it combines both a certain percentage of debt and equity in the capital structure and thus, the advantages of leverage (if any) is exploited. This mix of debt and equity has long been the subject of debate concerning its determination, evaluation and accounting.

Moreover, according to Barbosa and Louri (2005) various measures of performance have been identified in the literature, these include: productivity, profitability, customers satisfaction, etc. these variables are inter-related in one way or the other. Meanwhile, financial measures are indicators of financial strength, weaknesses, opportunities and threats of any firm. The proxies of financial performance include: Return on assets, return on investment, return on equity (residual income), dividend per share and earnings per share among others.Financial constraints have been a major factor affecting banking sector performance in developing countries especially Nigeria. The basis for the determination of optimal capital structure of banking sector in Nigeria is the widening and deepening of various financial markets. Mainly, the banking sector is characterized by a large number of firms operating in a largely deregulated and increasingly competitive environment. Since 1987, financial liberalization has changed the operating environment of banks, by giving more flexibility to the Nigerian financial managers in choosing their firms' capital structure. Alfred (2007) suggested that a firm's capital structure implies the proportion of debt and equity in the total capital structure of the firm. Pandey (1999) differentiated between capital structure and financial structure by affirming that the various means used to raise funds represent the firm's financial structure, while the capital structure represents the proportionate relationship between long-term debt and equity capital. Therefore, a firm's capital structure simply refers to the combination of long-term debt and equity financing. However, whether or not an optimal capital structure exists in relation to firm value, is one of the most important and complex issues in corporate finance.

Following the Structural Adjustment Program, lending rate rose to a high side from 1.5 percent in 1980 to a peak of 29.8 percent in 1992; but it declined to 16.9 percent in 2006 . The high interest rate implies that costs of borrowing went up in organized financial market, thus increased the cost of operations.It is critically observed by Warokka, Herrera and Abdulla (2011) that the subject of optimal capital structure has been the focus of several studies. This capital structure of a firm is a hybrid of debt and equity (be it common or preferred) employed in financing its operations. For a long time, it has been an imperative issue from the strategic management standpoint since it is linked with firm's ability to satisfy the demands of various stakeholders (Roy and Minfang, 2000)

Furthermore, this debt and equity are the two major classes of liabilities, with debt holders and equity holders representing two types of investors in the firm. Eachof this is associated with different level of risk, benefits, and control. While the debt holders exert lower control, they earn a fixed rate of return and are protected by contractual obligations with respect to their environment. Equity holders are residual claimants, bearing most 


\section{Sadiq et al.}

of the risks and have greater control over decisions.Capital structure decision is critical for the continued existence of any business organization as to the maximization of returns to the stakeholders (Akintoye, 2008). Literature revealed that several studies have been carried out to investigate the relationship that exist between capital structure and performance (Oaolapo and Kajola, 2010; Warokka et al, 2011). However, the results of these previous studies have been conflicting. While some researchers reported positive relationship between capital structure and banks performance (Akintoye, 2008; Dare and Sola, 2010), others reported negative relationship (Iorpev and Kwanum, 2012). Yet some researchers reported that no relationship exists between capital structure and performance (Prahalathan and Ranjan, 2011)

Moreover, the relationship that exists between capital structures andfirm's performances remains controversial one open to further research. The thrust of this research work is to create an obligation on the vital subject matter with a view to breaching the knowledge gap. Also, it will help us to know the potential problems in capital structure and performance.

\subsection{Objectives of the Research}

The focus of this study is to examine the effect of Capital Structure on firms financial Performance of the Banking industry listed in the Nigerian Stock Exchange. The other objectives are:

(a) To examine the effect of debt ratio on the financial performance of deposit money banks.

(b) To examine the effect of capital structure on return on asset and return.

\subsection{Hypothesis Development}

In line with the above objectives the following hypothesis is developed:

Ho: There is no significant relationship between capital structure and financial performance of Deposit Money Banks in Nigeria?

H1: There is a significant relationship between capital structure and the financial performance of Deposit Money Banks.

Ho: There is no significant relationship between debt, equity and the capital structure of the Deposit Money Banks.

H1: There is significant information between debt, equity and the capital structure of Deposit Money Banks

\section{Literature Review}

\subsection{Conceptual Framework}

A firm's capital structure refers to the mix ofits financial liabilities. As financial capital is an uncertain but critical resource for all firms, suppliers of finance are able to exert control over firms. There are two different ways of financing the assets of an organization, through equity or debt. Capital structure refers to the way a corporation finances its assets through some combination of equity and debt (Tsai, 2010). However, there are several kinds of equity and debt according to Mc Menain (1999) and Ross, et al (2005). These are common stock, preferred stock and retained earnings (untaxed reserve) reserve as well as bank loans, bonds, account payable and line to credit. Capital structure according to Song (2005) refers to the mix of different types of securities (long term debt,\& common stock) which are issued by a company to finance its assets. Chou (2007) sees capital structure as a mixture of debt and equity financing of a firm. Capital structure according to Wikipedia (2010), refers to the way a corporation finances itself through some combination of equity, debt or hybrid securities. From all the definitions above, it is eminent that capital structure in summary refers to the structure of a firm's liability. Hence, the capital structure theory is highly relevant to the firm's safety and 


\section{Sadiq et al.}

growth, as well as the debt holders safeguard for a sustainable economy. How to plan financing decision using a particular means or mix of funding to maintain a proper capital structure is an important issue of concern demanding urgent attention for financial managers if their sector is ever to play a major role in economic development.

Leverage is defined as the sensitivity of the value of equity ownership with respect to changes in the underlying value of the firm. Empirically, leverage ratios are frequently independent variables (sometimes as part of a hypothesis, or sometimes as a control). Leverage ratios are also the dependent variable in the empirical capital structure literature. This literature tries to explain variations in corporate leverage, both in the cross section of capital structure (i.e why some firms have high leverage) and in the time series (how capital structures evolve). Capital structure refers to the firm's financial framework which consists of the debt and equity used in financing the firm.

The ability of companies to carry out their stakeholders need is tightly related to capital structure. Therefore, this derivation is an important fact that we cannot omit. Capital structure in financial term means the way a firm finances its assets through the combination of equity, debt hybrid securities (Sa'ad, 2010). In short, capital structure is a mixture of a company's debts (long term and short term), common equity and preferred equity. Capital structure is essential on how a firm finances its overall operations and growth by using different sources of funds. Modigliani \&Miller (MM) theorem is the broadly accepted capital structure theory because it is the origin of capital structure theory which had been used by many researchers. According to MM theorem, these capital structure theories operate under perfect market. Various assumptions of perfect market such as no taxes, rational investors, perfect competition, absence of bankruptcy costs and efficient market. MM theorem states that capital structure of finances of a firm is not related to its value in perfect market.

For this purpose, capital structure can simply be defined as a firm's financial framework, which comprises of a firm retain earnings, debt financing and equity financing in order to maintain the business entity in financing its assets.

\subsubsection{Debt Financing}

Ihenetu, Iwo \& Ebiware (2016) defined debt capital in a firm's capital structure as the long term bonds the firm used in financing its investment decision because the firm has years if not decades to come up with the principal while paying interest in the meantime. The cost of debt in a firm's capital structure depends on the health of a firm's balance sheet. This can be expressed as:

$\mathrm{Kd}=\mathrm{Int} / \mathrm{Bo}$

Where Kd equals the before tax cost of debt

Int. is the interest element and Bo, the issue price of bond (debt).

The after taxcost of debt capital will be: $\mathrm{Kd}(1-\mathrm{T})$, where $\mathrm{T}$ is the corporate Tax rate.

\subsection{Review of Empirical Studies}

The available written literatures provide abundance of research which intends to look at the relationship between capital structure and Deposit Money Banks performance. Empirical results and arguments have gone both ways. Some researchers document that there is positive relationship between capital structure and firm performance, whereas others oppose by arguing that there is a negative effect on firm performance. Yet, there are some of the empirical evidences that yield contradictory and inconsistent findings.

Akinyomi (2013), using three manufacturing companies selected randomly from the food and beverage categories and a period of five years (2007-2011) using the static trade-off and the pecking order theory point of view. He adopted the use of correlation analysis method and revealed that each of debt to capital, debt to 


\section{Sadiq et al.}

common equity, short term debt to total debt and the age of the firms' is significantly and positively related to return on asset and return on equity but long term debt to capital is significantly and relatively related to return on asset and return on return on equity. His hypothesis also tested that there is significant relationship between capital structure and financial performance using both return on asset and return on equity. Abor (2005) investigate the relationship between capital structure and profitability of listed firms on Ghana Stock Exchange. He reveals a positive relationship between short term debt to total assets and return on equity due to low interest rates. He further, suggested that in Ghanaian firm's short term financing shows 85 percent of total debt and is considered a main element of financing for them. Moreover, a negative relationship found between long term financing and equity returns, and a positive relation exists between total debt and profitability. He also suggests that debt is considered as a major source of financing for high profitable firms.

Weill (2008) examines the relationship between financial leverage and firm's performance in seven European countries. He found that in Spain and Italy financial leverage relate significantly and positively with firms performance, while significantly and negatively in France, Norway, Germany and Belgium, but insignificantly in Portugal. Li Meng.(2008) also investigate that financial leverage has a negative relationship with firm performance measured by return on assets, but has a positive relation with return on equity. Nour A. (2012) studied Capital Structure and Firm Performance of Palestinian firms the results indicated that firm performance is positively related to capital structure and statistically significant with total debt to total assets except that market value of equity/ Book value of equity were significant with total debt to total assets \& short-term debt to total assets.

The study made by Daniel Kebede (2011), investigate the determinants of capital structure in Ethiopia's small scale manufacturing co operatives. The research method employed in the study is quantitative approach method specifically survey method. The findings of the study reveal that size and tangibility has positive relationship with leverage while profitability, earning volatility, growth and age has an inverse relationship with leverage.

WoldemikaelShibru (2012) examined the relationship between leverage and determinants of capital structure decision and to explore which capital structure theory is applicable in commercial banks in Ethiopia. He uses profitability, tangibility, growth, risk, size and liquidity as a factor that determine the mix of debt equity ratio. The results of the analysis indicate that profitability, tangibility, liquidity and growth have negative relationship with leverage. Size and leverage has a positive relationship. There is no support to identify the level of leverage is affected by risk.

Slz (1990) noted that debt can have both a positive and negative effect on the value of the firm (Even in the absence of corporate taxes and bankruptcy cost). He built a model in which over investment and under investment can be alleviated by debt financing. His model assumes that managers have no equity ownership in the firm and receive utility by managing a larger firm. The power of manager\| may motivate the self-interested managers to undertake negative present value project. In order to solve this problem, shareholders force firms to issue debt.

Ibrahim (2009) examined the impact of capital structure choice on firm performance in Egypt, using a multiple regression analysis in estimating the relationship between leverage level and firm's performance, the study cover between 1997 and 2005. Three accounting based measures of financial performance (return on Equity, return on Assets and gross profit margin) were used. The result revealed that capital structure choice decision in general, has a weak to-no impact on firm's performance.

Mohammadzadeh (2011) studied firms listed on Tehran Stock Exchange and found that firm's performance which is measured by (EPS \& ROA) is negatively related to capital structure. These findings are consistent to 


\section{Sadiq et al.}

Zeitun and Tian (2007) and Abor (2007) who indicate firm performance is negatively related to capital structure. Whileit's not consistent with findings of Berger and Bonaccors di Patti (2006) who revealed a positive relation between firm performance and capital structure. Ngoc-Phi-Anh D. \& Jeremy D. (2011) examined the relationship between firm characteristics, capital structure and operational performance among a sample of 427 companies listed on the Vietnamese stock exchange during the three years 2007-2009. The results showed that both long term debt and short term debt were negatively correlated to performance shown by return on asset (ROA), but positively correlated with the long-term assets ratio (LTDA) and negatively correlated with short term ratio (STDR).

Abdul (2012) researched on the relationship of capital structure decisions with firm performance of the engineering sector of Pakistan, the results showed that financial leverage measured by short term debt to total assets (STDTA) and total debt to total assets (TDTA) had a significantly negative relationship with the firm performance measured by Return on Assets (ROA), and return on equity (ROE) had negative but insignificant relationship with leverage. Firms in the engineering sector of Pakistan were largely dependent on short term debt but debts were attached with strong covenants which affected the performance of the firms. Ebaid (2009) reveal that capital structure has a very weak relationship with performance on the emerging market economy of Egypt. He shows that capital structure measured by short term, long term and total debt to total assets related insignificantly with firm's performance measured by return on equity. While short term debt and total debt to total assets related negatively and significantly with firms performance. Further, long term debt related negatively and insignificantly with performance measured by return on assets. Moreover, he also shows insignificant relationship between capital structure and gross profit margin.

\subsubsection{Equity Finance}

This entails the ability of the firms to raise its external finance from the public and at the same time issues out a part of the firms ownership right evidenced by share certificate. The equity holders are the first owners of the company. At the end of the financing period, the firms reward the equity holders with dividend from the profit made by the company (Efobi, 2008).

\subsubsection{Capital Structure Decision}

Capital structure decision is very important because it affects the balance sheet, shareholder's return and the share price of the firm (Nwude, 2003). That decision becomes even more difficult, in times when the economic environment in which the company operates presents a high degree of instability. Thus, the choice among the ideal proportion of debt and equity can affect the value of the company as much as return rates can (Mesquita and Lara 2003). The capital structure decision will involve decision on adopting the right combination of debt and equity for the firms' operations. A demand for raising additional funds according to Pandey (2011) generates a new capital structure since a decision has to be made as to the quantity and forms of financing. This decision will involve an analysis of the existing capital structure and the factors, which will govern the decision at present. An example of this factor is dividend decision. The company's policy to retain or distribute earnings affects the owners' claims.

\subsection{Theoretical Framework}

This section discusses theories as well as prior works in which relevant theories to this research topic are used. Theories are analytical tools for understanding, explaining and making predictions about a given subject matter. Thus, theories relevant to this study include cash cycle theory and financial theory

All modern researches have issues with the Modigliani and miller (1958) proposition which states that in a world of perfect capital market and no taxes, a firm's financial structure will not influence 


\section{Sadiq et al.}

its cost of capital. This proposition submitted that firms in a given risk class would be unaffected by financial gearing (Weston and Copeland 1998). Borigham and Gapenski (1996) argued that an optimal capital structure can be attained if there exist a tax sheltering benefits provided an increase in debt level is equal to the bankruptcy costs. They suggest that managers of a firm should be able to identify when the optimal capital structure is attained and try to maintain it at that level. This is the point at which the financing costs and cost of capital are minimized thereby increasing firms' value and performance.

The traditional view advocated that the value of the firm can be increased or the cost of capital can be reduced by the judicious mix of debt and equity capital. This theory very clearly implies that the cost of capital decreases within the reasonable limit of debt and then increases with leverage (Solomon 1963). Thus, an optimum capital structure exist and occur when the cost of capital is minimum or the value of the firm is maximum. The cost of capital declines with leverage because debt capital is cheaper than equity capital within reasonable or acceptable limit of debt. The statement that debt funds are cheaper than equity funds carried the clear implication that the cost of debt plus the increase cost of equity together on a weighted basis will be less than the cost of equity which existed on equity before debt financing (Barges 1963).

The study built on Modigliani and Miller theory which state that financial structure is invariant with market value of the firm.

\subsubsection{The Trade-Off Theory}

The trade-off theory of capital structure states that a firm's choice of its debt - equity ratio is a trade-off between its interest tax shields and the costs of financial distress. Thetheory further suggests that firms in the same industry should have similar or identical debt ratios in order to maximize tax savings. The tax benefit among other factors makes the after-tax cost of debt lower and hence the weighted average cost of capital will also be lower. This theory allows bankruptcy cost to exist. It states that there is an advantage to financing with debt (the tax benefits of debt) and that there is a cost of financing with debt (the bankruptcy costs and the financial distress costs of debt). The marginal benefit of further increases in debt declines as debt increases, while the marginal cost increases, so that a firm that is optimizing its overall value will focus on this trade -off when choosing how much debt and equity to use for financing (Modigliani and Miller (1963).Furthermore Brigham and Gapenski (1996) argue that an optimal capital structure can be obtained if there exist tax benefit which is equal to the bankruptcy cost. It can be concluded that, there is an optimal capital structure where the weighted average cost of capital is at its minimum. However, as a firm leverage ratio rises, tax benefits will eventually be offset by increases bankruptcy cost. The trade-off theory sought to establish an optimal capital structure where the weighted average cost of capital will be minimized and the firm value maximized. At the optimal level of capital structure, tax benefit will be equal to bankruptcy costs. Despite the theoretical appeal of debt financing, researchers of capital structure have not found the optimal capital structure (Simerly\& Li, 2002).

\subsubsection{Agency Theory of Capital Structure}

The agency cost theory of capital structure emanates from the principal-agent relationship (Jensen and Meckling, 1976). In order to moderate managerial behavior, debt financing can be used to mediate the conflict of interest which exists between shareholders and managers one hand and also between shareholder and bondholders on the other hand. The conflict of interest is mediated because managers get debt discipline which will cause them to align their goals to shareholders goals.

Jensen and Meckling (1976) and Jensen and Ruback (1983) argue that, managers do not always pursue shareholders interest. To mitigate this problem, the leverage ratio should increase (Pinegar 


\section{Sadiq et al.}

and Wilbricht, 1989). This will force the managers to invest in profitable ventures that will be of benefit to the shareholders. If they decide to invest in non-profit tax businesses or investment and are not able to pay interest on debt, then the bondholders will file for bankruptcy and they will lose their jobs. The contribution of the Agency cost theory is that, leverage firms are better for shareholders as debt can be used to monitor managerial behavior (Boodhoo, 2009). Thus, higher leverage is expected to lower agency cost, reduce managerial inefficiency and thereby enhancing firm and managerial performance (Jensen 1986, Koehhar 1996, Aghion, Dewatnipont and Rey, 1999).

\subsubsection{Pecking Order Theory of Capital Structure}

The pecking order theory is geared towards the signaling effect of the use of debt financing. According to the pecking order theory firms prefer financing their operations from internally generated funds, because the use of such funds does not send any negative signal that may lower the stock price of the firm. If internal finance is required, firms prefer to issue debt first before considering the issue of equity. The theory tries to capture the costs of asymmetric information. It states that companies prioritize their sources of financing (from internal financing to issuing shares of equity) according to least resistance, preferring to raise equity for financing as a last resort. Internal financing is used first. When that is depleted, debt is issued. When it is no longer sensible to issue any more debt, equity is issued. This theory maintains that businesses adhere to a hierarchy of financing sources and prefer internal financing when available, while debt is preferred over equity if external financing is required. Thus, the form of debt a firm chooses can act as a signal of its need for external finance. This pecking order occurs because issuing debt is less likely to send a negative signal to investors. If a firm should issue equity it sends a negative signal to investors that the firm's share prices are overvalued that is why the managers are issuing equity. This will cause investor to sell their shares leading to a fall in the stock price of the firm. A share issue is thus interpreted by the market as a bad omen but debt is less likely to be interpreted this way. Firms therefore prefer to issue debt rather than equity if internal finance is insufficient. The pecking order theory is therefore a competing theory of capital structure that says firms prefer internal financing.

\section{Research Methodology}

This highlights the research methodology adopted by the researcher for the entire study. It includes the research design, population of the study, sample size, and measures or variables of the study. This is done in order that a complete appreciation of the instruments and techniques will provide armful justification to the research.

The researcher employed an ex-post facto research design which implies that it will utilize secondary data listed on Nigerian Stock Exchange.Information for evaluating such influences on profitability can best be obtained from the historical data documented in the annual reports and accounts of the quoted banking industry. Impliedly the phenomenon observed (the impact of capital structure on the performance of Deposit Money Banks).

The population of this research work encompasses all the banks listed on the Nigerian Stock Exchange (NSE) as at 31 December, 2015.

Table1 Presents the Population of the Study

\begin{tabular}{ll}
\hline $\mathbf{S} / \mathbf{N}$ & Name of The Bank \\
\hline 1 & Access Bank \\
\hline 2 & Diamond Bank Plc \\
\hline 3 & Ecobank Transntaional Incorporated \\
\hline 4 & Fidelity Bank Nigeria \\
\hline
\end{tabular}




\begin{tabular}{ll}
\hline 5 & First Bank of Nigeria \\
\hline 6 & First City Monument Bank \\
\hline 7 & Guaranty Trust Bank \\
\hline 8 & Skye Bank \\
\hline 9 & Stanbic IBTC Bank Nigeria Limited \\
\hline 10 & Sterling Bank \\
\hline 11 & Union Bank of Nigeria \\
\hline 13 & United Bank for Africa \\
\hline 14 & Unity Bank Plc. \\
\hline 15 & Zenith Bank \\
\hline
\end{tabular}

Source: NSE Fact book, 2017

A sample is a representative part of the population under observation. For the purpose of this study, a sample size of one-third i.e four banks from the population was picked using judgmental sampling method is the sampling techniques adopted in this research because it is the fundamental method of probability sampling. This method uses the principles of randomization, which is a procedure of giving every subject in the population an equal opportunity of being selected. The selected banks are:

Table 2 Quoted Banks

\begin{tabular}{ll}
\hline S/N & Quoted Banks \\
\hline 1 & Access Bank \\
\hline 2 & Stanbic Ibtc \\
\hline 3 & Sterling Bank \\
\hline s4 & Diamond Bank \\
\hline
\end{tabular}

Source: NSE Fact-book, 2017

\section{Measures of the Study}

Debt/Equity

$=$ Debt Equity

ROA (Return on Asset)

$=$ PAIT Assets

ROE (Return on Equity)

$=\quad$ PAIT Equity

\section{ROCE (Return on Capital Employed $)=\quad$ PBIT Assets}

From the above measures, Debt to equity ratio is the independent variable. While return on asset ROA, Return on equity ROE and return on equity ROCE constitute the dependent variables

\section{Result and Discussion}

\subsection{Descriptive Result}

Table 3: Descriptive Statistics

\begin{tabular}{llllll}
\hline Variable & Obs & Mean & Std. Dev & Min & Max \\
\hline DE & 40 & 8.90425 & 13.54219 & -.09 & 67.92 \\
\hline ROA & 40 & .0175 & 0.164473 & -.03 & .07 \\
\hline ROE & 40 & .162 & .2642182 & -.27 & 1.23 \\
\hline ROCE & 40 & .022 & .202801 & -.03 & .09 \\
\hline
\end{tabular}

Table 3 shows the descriptive statistics of the study variables.Results shown in table 3 present a mean Returns on Assets (roa) of about .0175 for the selected firms under consideration. This represents an averaged 


\section{Sadiq et al.}

percentage distribution of about $1.8 \%$ for the period, the mean returns on equity (roe) is about .162 and 0.022 for retunes on Capital Employed (roce). On the other hand; Debt equity maintains an averaged mean distribution value of about 8.904 for the sampled listed banks in the Nigerian stock exchange market. The standard deviation result shows that roa, roe and roce did not deviate much from their mean as they report a standard deviation of $0.02,0.26$ and 0.02 respectively.

\subsection{Correlation Result}

Table 4: Correlation Matrix

\begin{tabular}{|c|c|c|c|c|}
\hline & DE & ROA & ROE & ROCE \\
\hline DE & 1.0000 & & & \\
\hline ROA & -0.1099 & 1.0000 & & \\
\hline ROE & 0.8921 & 0.2089 & 1.0000 & \\
\hline ROCE & -0.1459 & 0.9532 & 0.1758 & 1.0000 \\
\hline
\end{tabular}

Further, empirical findings from the Pearson correlation analysis presented in table 4 on the relationship between capital structure and the financial performance of Deposit Money Banks show that there is a positive relationship between roe and de with a correlation coefficient ( $\mathrm{r}$ ) of 0.89 , this implies that an increase in roa will lead to an increase in de. However, roa and roce have a negative relationship with de. A correlation coefficient of -0.1099 and -0.1459 for roa and roce respectively shows a weak negative relationship. This implies that an increase in roa and roce will lead to a decreased capital structure of the sampled banks.

This shows that there is enough empirical evident to reject the null hypothesis which states that there is no relationship between capital structure and financial performance of deposit money banks listed at the Nigerian Stock Exchange.

\subsection{Regression Result}

Table 5: Regression Result

\begin{tabular}{lllllll}
\hline DE & $\begin{array}{l}\text { Unstandardized } \\
\text { Coefficients }\end{array}$ & \multicolumn{2}{c}{$\begin{array}{l}\text { Standardized } \\
\text { Coefficients }\end{array}$} & P> & (z) & $\begin{array}{l}\text { 95\% Conf. } \\
\text { Interval }\end{array}$ \\
\cline { 2 - 5 } & Coef & Std. Error & $\mathbf{Z}$ & & & \\
\hline ROA & -90.94449 & 150.9383 & -0.60 & 0.547 & -386.7781 & 204.8891 \\
\hline ROE & 48.78168 & 2.885045 & 16.91 & 0.000 & 43.1271 & 54.43627 \\
\hline ROCE & -.138 .8695 & 121.6059 & -.1 .14 & 0.253 & -377.2127 & 99.47363 \\
\hline CONS & 5.648276 & 1.136199 & 4.97 & 0.000 & 3.421366 & 7.875185 \\
\hline
\end{tabular}

\footnotetext{
Group variable: bank

R-sq: $\quad$ within $=0.8994$

Between $=0.8692$

Overall $=0.8916$
}

Random-effects GLS regression

Results from the random effect GLS regression presented in table 5 indicates that the financial performance variables (independent variables) used in this study are enough to explain the variation in capital structure of the banks under consideration. The coefficients of determinants R2 which are 0.8994, 0.869 and 0.892 for within the group, between the group and the overall R2respectively. The R-Squared which is also a measure of the 


\section{Sadiq et al.}

overall fitness of the model indicates that the model is capable of explaining $89 \%$ of the variability. This means that the model explains $89 \%$ of the systematic variation in the dependent variable. That is, about $11 \%$ of the variations in capital structure policies of the sampled firms are accounted for by other factors not captured by the model.

The result further shows that roa androce have negative impact on de. The p-value for the independent variables 0.57 and 0.253 respectively are insignificant at 0.05 confidence level. The coefficient of both variables indicates that roa and roce have a negative effect on de with a coefficient of -90.944 and -138.87 respectively.

However, roe have a positive effect on de with a coefficient of 48.782, a p-value of 0.000 further shows that it is significant at 0.05 level of significance, thereby leading to the rejection of the null hypothesis which states that capital structure have no significant effect on financial performance of deposit money bank firms listed in the Nigerian Stock Exchange.

\section{Conclusion and Recommendation}

\subsection{Conclusion}

The study seeks to find the effect of capital structure on financial performance of listed deposit money banks in Nigeria for a period of 10 years. Four banks were selected as samples and findings show that there is $\mathrm{s}$ relationship between capital structure and the financial performance of deposit money banks in Nigeria.Furthermore, result also indicate that capital structure have a significant effect on the financial performance of listed deposit money banks in Nigeria.

\subsection{Recommendation}

Based on these results, it is recommended that deposit money banks in Nigeria should employ an appropriate mix of debt and equity capital in order to maximize return on investment and achieve an optimum capital structure. The banks should therefore strike a balance between their choice of capital structure and its effect on their performance as this will affect the shareholders risk returns and the cost of capital. Furthermore, the banks shouldincrease their assets as this will help them to be more positioned for better performance. Lastly, the Government should improve liquidity in the Nigerian Financial Market by liaising with stakeholders in the financial sector so as to develop the bond market and enable deposit money banks raise long term debt.

\section{References}

Abdul G. (2012). The Relationship of Capital Structure Decisions with Firm Performance: A Study of the Engineering Sector of Pakistan. International Journal of Accounting and Financial Reporting, 2(1).

Abor, J. (2005). The Effect of Capital Structure on Profitability: An Empirical Analysis of Listed Firms in Ghana. Journal of Risk Finance, 6, 438-447.

Akintoye, I. R. (2011).Sensitivity of Performance to Capital Structure. European Journal of Social Science, 7(1): 163-144.

Akinyomi, O. J. (2013).Effect of Capital Structure on Firms Performance: Evidence from Nigerian Manufacturing Company. International Journal of Innovative Research and Studies, 2(9).

Alfred, D. D. (2007). Corporate Finance: Issues, Investigations, Innovations and Applications (2nd ed.). Lagos: High Rise Publication.

Brealey R.A and Myers S.C. (2001). Principles of Corporate Finance.Sixth edition, McGraw-Hill Irin companies, 1333 Burr Ridge Parkway, Burr Ridge, IL 60521.

Brealey R.A., Myers S.C. and Allen F. (2006). Corporate Finance.Eighth Edition, McGraw-Hill Irin companies, Inc.1221 Avenue of the Americas, New York, NY 10020.

Boodhoo,R (2009).Capital structure and Ownership Structure:are view of literature.The Journal 
Sadiq et al.

of Online Education, January Edition, 1-8.

Dittman A.Thakor A. (2007).Why do Firms Issue Equity?. The Journal Finance,1(1), 1-54.

Inanga, E. L., and Ajayi, C. A. (1999).Accountancy. Lagos: The CIBN Press Limited.

Iorpev, L. and Kwanum, I. M.(2012).Capital Structure and Firm Performance: Evidence from Manufacturing

Companies in Nigeria. International Journal of Business and Management Tomorrow, 2(5), 1-7.

Jensen,M and Ruback,R(1983).The Market for Corporate Control:the Scientific Evidence.Journal of Financial Economics, 11,5-50.

Jensen, M. and Meckling W. (1976). Theory of the Firm: Managerial Behavior, Agency Costs and Ownership Structure. Journal of Financial Economics, 3, 305-60.

Modigliani, F. and Miller, M. H. (1958).The Cost of Capital, Corporate Finance and the Theory of Investment.American Economic Review, 48, 261-97.

Myers, S. C. and N. S. Majluf (1984).Corporate Financing and Investment Decisions. When Firms Have Information That Investors Do Not Have.Journal ofFinancial Economics, 13, 187-222.

Ngoc-Phi-Anh D. \& Jeremy D.(2011). Firm Characteristics, Capital Structure and Operational Performance: A Vietnamese Study. APEA 2011 Conference Pusan National University, Busan, Korea.

Nour A.(2012). Capital Structure and Firm Performance; Evidence from Palestine Stock Exchange.Journal of Money, Investment and Banking,23.

Onaolapo, A and Kajola, S. (2010).Capital Structure and Firm Performance: Evidence from Nigeria.European Journal of Economics, Finance and Administrative Sciences.

Pandey, I. M. (1999).Financial management (8th ed.). New Delhi: Vikas PublishingHousePVT Ltd.

Roy, L. and Minfang, L. (2000).Environmental Dynamism, Capital Structure and Performance: A theoretical Integration and an Empirical Test. Strategic Management Journal.

Sa'ad, N. M. (2010).Corporate Governance Compliance and the Effects to Capital Structure. International Journal of Economics and Financial, 2(1),105-114.

Smirlock,M.(1985).Evidence on the non- Banking. Journal of Money, Credit, and Banking, 17(1),69-83.

Tsuji, C. (2011). Recent Development of the Agency Theory and Capital Structure. Economics and Finance Review, 1(6), 94-99.

Warokka, A., Herrera, J. J., and Abdullah, H. H. (2011).East Asian Corporate Governance: A Test of the Relation between Capital Structure and Firm Performance. International Journal of Economics and Finance Studies, 3(2),1-10.

Weill, L. (2008). Leverage and Corporate Performance: Does Institutional Environment Matter?. Small Business Economics, 30(3), 251-265.

Zeitun, R. \&Tian, G. G. (2007).Capital structure and Corporate Performance: Evidence from Jordan. Australasian Accounting Business and Finance Journal.1(1).

\section{Copyrights}

Copyright for this article is retained by the author(s), with first publication rights granted to the journal. 